\title{
Pengaruh Kombinasi Senam Kegel Dan Relaksasi Nafas Dalam Terhadap Nyeri Luka Perineum Pada Ibu Nifas
}

\author{
Arnita Rizka Amarina ${ }^{1}$, Irmayani ${ }^{2}$, Sudarmi $^{3}$ \\ 1,2,3 Jurusan Kebidanan Poltekkes Kemenkes Mataram, Kementerian Kesehatan RI
}

Abstrak

Latar Belakang : ibu nifas akan mengalami berbagai gangguan dan yang terbanyak adalah gangguan nyeri yang mencapai $70,9 \%$. Penyebab utama nyeri tersebut adalah jahitan perineum dari fenomena yang terjadi untuk mengurangi nyeri ibu bisa melakukan relaksasi nafas dalam dan senam kegel.

Tujuan : untuk mengetahui pengaruh kombinasi senam kegel dan relaksasi nafas dalam terhadap nyeri luka perineum pada ibu nifas di UPT BLUD Puskesmas Meninting

Metode : penelitian ini menggunakan rancangan penelitian Quasi experiment dengan jenis Pre and Post Test With Control Group Design. Populasi adalah seluruh ibu nifas, sample diambil dengan Purposive Sampling dengan jumlah sampel 30 responden. Analisa data menggunakan analisis univariat dan bivariat menggunakan Kruskal Wallis

Hasil : Nyeri perineum pada ibu nifas sebelum dan sesudah dilakukan senam kegel memiliki rata-rata selisih yaitu 3,60 dan mean rank 11,45. Relaksasi nafas dalam memiliki rata-rata selisih yaitu 3,50 dan mean rank 11,35. Kombinasi senam kegel dan relaksasi nafas dalam memiliki rata-rata selisih yaitu 5,50 dan mean rank 23,70. Uji statistik menggunakan Kruskal wallis hasil didapatkan ada pengaruh senam kegel dan relaksasi nafas dalam dengan p-value $0,001<\alpha 0,05$.

Kesimpulan : Ada pengaruh kombinasi senam kegel dan relaksasi nafas dalam terhadap nyeri luka perineum pada ibu nifas

Kata Kunci : Senam Kegel ; Relaksasi ; Nyeri Perineum

\section{The Effect Combination Of Kegel Exercise And Deep Breath Relaxation To Wound Pain Perineum Of Post Partum}

\begin{abstract}
Background: post partum mothers will experience various disorders and the most is pain disorders that reach $70.9 \%$. The main cause of the pain is the perineal suture from the phenomenon that occurs to reduce the pain of the mother can do deep breath relaxation and kegel exercise

Aim : To determine the effect of combination kegel exercise and deep breath relaxation on perineal wound pain in postpartum mothers in UPT BLUD Meninting Health Center

Methods : this study used Quasi Experimental research design with the type of Pre and Post Test With Control Group Design. The population of this research that all childbirth mother, samples were taken by purposive sampling with a sample of 30 respondents. Analysis of the data using univariate and bivariate analyses using Kruskall Wallis.

Results : Perineal pain in post partum women before and after Kegel exercises has an average difference of 3.60 and mean rank 11.45. Deep breath relaxation has an average difference of 3.50 and mean rank 11.35. The combination of Kegel exercises and deep breathing relaxation has an average difference of 5.50 and mean rank 23.70. The statistical test using Kruskal wallis results showed there was the effect combination of kegel exercise and deep breath relaxation with p-value $0.001<\alpha 0.05$.

Conclusion: There is an effect of the combination of kegel exercise and deep breathing relaxation on perineal wound pain on postpartum mothers
\end{abstract}

Keywords: Kegel Exercises ; Deep Breath Relaxation ; Perineal Pain 


\section{Pendahuluan}

Post partum atau nifas merupakan keadaan dimana masa pemulihan alat- alat reproduksi seperti sebelum hamil. Dalam masa nifas perlu melakukan perawatan untuk membantu proses involusi misalnya mobilisasi, diet, miksi, defekasi, laktasi, perawatan payudara dan dan perawatan perineum ${ }^{1}$

Proses persalinan hampir 90\% yang mengalami robekan perineum, baik dengan atau tanpa episiotomi $^{(2)}$ Ibu nifas akan mengalami berbagai gangguan, salah satunya yang terbanyak adalah gangguan nyeri yang mencapai 70,9\%. Penyebab utama nyeri tersebut adalah jahitan perineum.

Sebagian besar AKI terjadi saat persalinan terutama karena perdarahan. Ibu bersalin umumnya mengalami robekan pada vagina dan perineum yang menimbulkan perdarahan dalam jumlah bervariasi dan banyak. Sehingga robekan perineum memerlukan penjahitan. Luka dan penjahitan pada perineum harus dirawat dengan baik karena bila tidak akan menimbulkan masalah seperti infeksi dan nyeri ${ }^{3}$

Berdasarkan hasil penelitian Evi Nur Imamah tentang pengaruh teknik relaksasi terhadap penurunan nyeri luka perineum pada ibu post partum menunjukkan bahwa dari 20 responden dengan luka jahitan perineum sebelum dilakukan teknik relaksasi mengalami nyeri sedang sebanyak 17 orang dan berkurang menjadi ringan sebanyak 11 orang (55\%) dan tidak merasa nyeri sebanyak 9 orang (45\%) yang menunjukkan bahwa teknik relaksasi adalah salah satu teknik terapi non farmakologi dalam mengurangi nyeri. $^{4}$

Berdasarkan laporan PWS KIA di UPT BLUD Puskesmas Meninting pada bulan Desember tahun 2018 cakupan untuk ibu nifas yaitu 1045 orang (84.68\%) dari total sasaran yaitu 1234 orang (95\%). Berdasarkan uraian di atas, maka peneliti tertarik mengadakan penelitian tentang "Pengaruh Kombinasi Senam Kegel dan Relaksasi Nafas Dalam terhadap nyeri luka perineum pada ibu post partum di wilayah kerja UPT BLUD Puskesmas Meninting”.

\section{Metode}

Penelitian ini menggunakan jenis penelitian Quasi Eksperimen dimana peneliti melakukan perlakuan tertentu terhadap sejumlah objek dengan Pre and Post Test With Control Group Design. Pengambilan sampel pada penelitian ini menggunakan teknik Purposive Sampling, karena sampel yang ditentukan dengan pertimbangan tertentu sesuai dengan kriteria inklusi dan ekslusi. ${ }^{5}$

Penelitian ini dilaksanakan pada bulan April-Mei 2019. Besar sampel pada penelitian ini adalah $30 \mathrm{ibu}$ nifas. Analisis univariat bertujuan untuk mendeskripsikan karakteristik masing-masing variable yang diteliti, sedangkan analisis bivariat bertujuan untuk menguji pengaruh variabel bebas terhadap variabel terikat.

\section{Hasil dan Pembahasan}

Tabel 1. Distribusi responden berdasarkan umur

\begin{tabular}{|c|c|c|}
\hline \multirow[t]{2}{*}{ Umur } & \multicolumn{2}{|c|}{ Intervensi } \\
\hline & $\mathrm{N}$ & $\%$ \\
\hline$<20$ tahun & 9 & 30 \\
\hline 20-35 tahun & 21 & 70 \\
\hline$>35$ tahun & 0 & 0 \\
\hline Jumlah & 30 & 100 \\
\hline
\end{tabular}


Berdasarkan tabel 1 diatas diperoleh sebagian besar responden berada pada kisaran umur 20-35 tahun, yaitu berjumlah 21 orang $(70 \%)$, dan sebagian kecil berumur $<20$ tahun yaitu berjumlah 9 orang $(30 \%)$.

Tabel 2. Distribusi responden berdsarkan pendidikan

\begin{tabular}{lll}
\hline Pendidikan & \multicolumn{2}{c}{ Intervensi } \\
\cline { 2 - 3 } & $\mathrm{N}$ & $\%$ \\
\hline Tidak Sekolah & 1 & 3,3 \\
SD & 10 & 33,3 \\
SMP & 9 & 30 \\
SMA & 10 & 33,3 \\
PT & 0 & 0 \\
\hline Jumlah & 30 & 100 \\
\hline
\end{tabular}

Berdasarkan tabel 2 diatas tingkat pendidikan responden didominasi oleh ibu yang tingkat pendidikannya SMA dan SD yaitu sebanyak 20 orang $(66,6 \%)$ dan tingkat pendidikan paling rendah yaitu tidak sekolah sebanyak 1 orang $(3,3 \%)$

Tabel 3. Distribusi responden berdasarkan pekerjaan

\begin{tabular}{lll}
\hline \multirow{2}{*}{ Pekerjaan } & \multicolumn{2}{c}{ Intervensi } \\
\cline { 2 - 3 } & $\mathbf{n}$ & $\mathbf{\%}$ \\
\hline Tidak Bekerja & 25 & 83,3 \\
Bekerja & 5 & 16,7 \\
\hline & 30 & 100 \\
\hline
\end{tabular}

Berdasarkan tabel 3 diatas responden lebih banyak yang tidak bekerja dibandingkan dengan yang bekerja, dimana responden yang tidak bekerja sebanyak 25 orang $(83,3 \%)$, dan yang bekerja sebanyak 5 orang $(16,7 \%)$

Tabel 4. Analisis berdasarkan selisih Rata-rata Pengaruh senam kegel dan relaksasi nafas dalam sebelum dan sesudah terhadap nyeri luka perineum pada ibu nifas

\begin{tabular}{llll}
\hline Intervensi & & p-value & Keterangan \\
\hline Relaksasi & Senam kegel & 0,962 & Tidak signifikan \\
& kombinasi & 0,000 & Signifikan \\
\hline Senam kegel & Relaksasi & 0,962 & Tidak signifikan \\
& kombinasi & 0,000 & Signifikan \\
\hline
\end{tabular}

Berdasarkan tabel 4 diatas dapat dilihat bahwa tingkat nyeri perineum pada ibu nifas sebelum dan sesudah dilakukan senam kegel memiliki rata-rata selisih yaitu 3,60, dengan standar deviasi 0,69 dan mean rank 11,45. Relaksasi nafas dalam memiliki rata-rata selisih yaitu 3,50 dengan standar deviasi 0,70 dan mean rank 11,35. Sedangkan kombinasi senam kegel dan relaksasi nafas dalam memiliki rata-rata selisih yaitu 5,50 dengan standar deviasi 1,08 dan mean rank 23,70

Tabel 5. Analisis Komparasi Ganda Pengaruh senam kegel dan relaksasi nafas dalam terhadap nyeri luka perineum pada ibu nifas

\begin{tabular}{|c|c|c|c|c|c|c|c|}
\hline \multirow[t]{2}{*}{ Intervensi } & \multirow[t]{2}{*}{ n } & & & & & \multirow[t]{2}{*}{$\begin{array}{l}\text { Mean } \\
\text { rank }\end{array}$} & \multirow[t]{2}{*}{$\begin{array}{l}\text { P- } \\
\text { Value } \\
\end{array}$} \\
\hline & & mean & $\min$ & Max & SD & & \\
\hline Senam & 10 & 3,60 & 3 & 5 & 0,69 & 11,45 & \multirow{3}{*}{0,001} \\
\hline Relaksasi & 10 & 3,50 & 2 & 4 & 0,70 & 11,35 & \\
\hline Kombinasi & 10 & 5,50 & 4 & 7 & 1,08 & 23,70 & \\
\hline
\end{tabular}


Berdasarkan tabel 5 Hasil perhitungan dengan Uji One Way Anova. Dari hasil penelitian didapatkan Hasil uji statistik didapatkan nilai $\mathrm{p}=0,000<\alpha=0,05$, maka dapat disimpulkan bahwa ibu nifas yang diberikan kombinasi senam kegel dan relaksasi nafas dalam terhadap lebih memberikan pengaruh yang signifikan terhadap nyeri luka perineum pada ibu nifas dibandingkan hanya diberikan senam kegel atau relaksasi nafas dalam saja

\section{Karakteristik Responden}

Umur

Rentang umur responden dalam penelitian ini sebagian besar adalah kisaran 20-35 tahun dengan presentase $70 \%$. Usia Umur ibu yang lebih muda memiliki sensori nyeri yang lebih intens dibanding dengan ibu yang memiliki umur yang lebih tua. Umur muda cenderung dikaitkan dengan kondisi psikologis yang masih labil yang memicu terjadinya kecemasan sehingga nyeri yang dirasakan semakin lebih kuat.

Usia kisaran 20-35 tahun masih dalam masa produktif dan daya tangkap ibu terhadap segala bentuk informasi yang disampaikan akan mempengaruhi pengetahuan ibu Responden dengan umur yang semakin dewasa tingkat kematangan dan kekuatan seseorang akan lebih baik dalam berpikir maupun bekerja sehingga dapat mendukung dalam pelaksanaan senam kegel dan relaksasi nafas dalam yang dilakukan oleh ibu nifas. ${ }^{6}$

\section{Pendidikan}

Tingkat pendidikan respoden dalam penelitian ini penelitian ini yang terbanyak yaitu responden dengan pendidikan Sekolah Dasar dan Sekolah Menengah Atas (66,6\%)

Tingkat pendidikan merupakan salah satu faktor yang menentukan terhadap terjadinya perubahan perilaku, dimana semakin tinggi tingkat pendidikan seseorang, maka seseorang telah mengalami proses belajar yang lebih sering, dengan kata lain tingkat pendidikan mencerminkan intensitas terjadinya proses belajar. $^{7}$

Tingkat pendidikan berpengaruh terhadap kecemasan, semakin tinggi pendidikan maka semakin mudah pula orang tersebut menghadapi masalah. Demikian pula pendidikan dapat mempengaruhi proses belajar, makin tinggi pendidikan seseorang makin mudah orang tersebut menerima informasi ${ }^{8}$

Tingkat pendidikan pada responden juga pada kategori tingkat pendidikan tinggi yang lebihbanyak sehingga ibu mengetahui untuk lebih menjaga kesehatan. Pendidikan memiliki peranan penting dalam menentukan kualitas hidup manusia.

\section{Pekerjaan}

Hasil penelitian menunjukan sebagian besar responden sebagai ibu rumah tangga dengan persentase $83,3 \%$, sebagai wiraswasta/pedagang $13,3 \%$ dan sebagai swasta 3,3\%. Ibu yang tidak bekerja atau sebagai ibu rumah tangga mempunyai banyak waktu dirumah dibandingkan dengan ibu yang mempunyai pekerjaan sehingga mereka cenderung jenuh dan tidak terlalu banyak bertukar pikiran denganorang-orang disekitar

Seseorang yang tidak bekerja akan berkonsentrasi penuh saat menghadapi masa nifasnya dan tidak ada beban untuk menyelesaikan tuntutan pekerjaan, karena dengan adanya pekerjaan sangat mengganggu 
untuk fokus terhadap diri sendiri dan mengasuh bayi saat nifas. Sehingga mempermudah untuk melakukan senam kegel dan relaksasi nafas dalam pada ibu nifas.

\section{Tingkat nyeri luka perineum ibu nifas sebelum dan sesudah diberikan senam kegel dan relaksasi nafas dalam.}

Dalam penelitian ini tingkat nyeri perineum pada ibu nifas sebelum dan sesudah dilakukan senam kegel memiliki rata-rata selisih yaitu 3,60, dengan standar deviasi 0,69 dan mean rank 11,45. Relaksasi nafas dalam memiliki rata-rata selisih yaitu 3,50 dengan standar deviasi 0,70 dan mean rank 11,35.

Sedangkan kombinasi senam kegel dan relaksasi nafas dalam memiliki rata-rata selisih yaitu 5,50 dengan standar deviasi 1,08 dan mean rank 23,70. Sehingga dapat disimpulkan bahwa kombinasi senam kegel dan relaksasi memiliki rata-rata selisih yang paling besar dan nilai mean rank yang lebih besar sehingga lebih efektif dalam menurunkan nyeri luka perineum pada ibu nifas

Hasil penelitian ini sejalan dengan hasil penelitian Makzizatunnisa dkk yang menunjukkan bahwa Ada perbedaan nyeri perineum sebelum dan sesudah relaksasi nafas dalam diperoleh nilai p-value 0,007 dimana $0,007<0,05$. Ada pengaruh nyeri perineum setelah senam kegel dibandingkan setelah relaksasi nafas diperoleh nilai p-value 0,036 dimana $0,036<0,05$

\section{Pengaruh senam kegel dan relaksasi nafas dalam terhadap nyeri luka perineum pada ibu nifas}

Setelah dilakukan uji statistic menggunakan Kruskal Wallis, kemudian dilakukan komparasi ganda untuk melihat efektifitas dari intervensi yang diberikan menggunakan Uji One Way Anova pada system komputerisasi SPSS 22.0. Dari hasil penelitian didapatkan Hasil uji statistik didapatkan nilai p $=0,000<$ $\alpha=0,05$, maka dapat disimpulkan bahwa ibu nifas yang diberikan kombinasi senam kegel dan relaksasi nafas dalam lebih memberikan pengaruh yang signifikan terhadap nyeri luka perineum pada ibu nifas dibandingkan hanya diberikan senam.

Senam kegel dapat melatih otot-otot dasar panggul, otot-otot vagina, perut, yang pada saat persalinan pervaginam mengalami peregangan dan kerusakan terutama bagian perineum dapat menyebabkan nyeri setelah melahirkan, dengan melakukan senam kegel, otot-otot akan kembali pulih seperti semula sehingga ibu tidak lagi mengalami nyeri.

Selain itu dengan melakukan senam kegel akan memperlancar peredaran darah menuju perineum, keadaan darah yang kaya akan oksigen yang bersih diharapkan akan membantu dalam proses penyembuhan 9

Serta teknik relaksasi merupakan salah satu cara non-farmakologis untuk mengurangi rasa nyeri luka jahitan perineum pada ibu post partum. Dalam keadaan kaya akan oksigen yang bersih diharapkan metabolisme didalam tubuh akan berjalan dengan baik dan otak akan relaksasi sehingga impuls nyeri yang diterima akan diolah dengan baik dan diterjemahkan dengan persepsi nyeri yang berkurang.

Hal ini sesuai dengan penelitian Makzizatunnisa, Eni Kusyati, Nurul Hidayah bahwa didapatkan hasil p-value 0,036 yaitu Senam kegel lebih efektif di bandingkan dengan relaksasi nafas dalam terhadap nyeri perinium pada ibu post partum. Direkomendasikan untuk melakukan melakukan senam kagel atau relaksasi nafas untuk mengurangi nyeri perineum pada ibu. ${ }^{3}$ 


\section{Kesimpulan}

Karakteristik umur ibu nifas sebagian besar berusia 20-35 tahun dengan persentasi 70\%, berpendidikan SMA dan SD dengan presentase 66,6 \%, tidak bekerja dengan persentasi 83,3\%. Tingkat nyeri perineum pada ibu nifas sebelum dan sesudah dilakukan senam kegel memiliki rata-rata selisih yaitu 3,60, dengan standar deviasi 0,69 dan mean rank 11,45. Relaksasi nafas dalam memiliki rata-rata selisih yaitu 3,50 dengan standar deviasi 0,70 dan mean rank 11,35. Sedangkan kombinasi senam kegel dan relaksasi nafas dalam memiliki rata-rata selisih yaitu 5,50 dengan standar deviasi 1,08 dan mean rank 23,70. Sehingga dapat disimpulkan bahwa kombinasi senam kegel dan relaksasi memiliki rata-rata selisih yang paling besar dan nilai mean rank yang lebih besar sehingga lebih efektif dalam menurunkan nyeri luka perineum pada ibu nifas

\section{Daftar Pustaka}

1. Basuki Dwi FL. Gambaran Proses Penyembuhan Luka Perineum Pada Nifas Hari Ke 1 Sampai 14 di BPS Umi Nadifah Pelintah Kec. Pandaan Pasuruan. J Keperawatan Bina Sehat. 2012; Vol 7 No.1.

2. Annisa, Ridhyanti. Hubungan Antara Senam Kegel Dengan Penyembuhan Luka Jahitan Perineum Pada Ibu Post Partum Normal Tahun 2013. Skripsi Stikes Aisyiyah Bandung.

3. Makzizatunnisa dan Eni Kusyanti NH. Efektifitas Senam Kegel Dan Relaksasi Nafas Dalam Terhadap Nyeri Perinium Pada Ibu Post Partum Di Bpm Prima Boyolali.Vol 3 No 1 2014;

4. Evi Nur Imamah. Pengaruh Teknik Relaksasi Terhadap Penurunan Nyeri Luka Jahitan Perineum Pada Ibu Post Partum. Jurnal Keperawatan Sriwijaya, Volume 7 Nomor 2, Juli 2020

5. Sugiyono. 2014. Metode Penelitian. Bandung: Alfabeta

6. Mubarak. 2017. Promosi Kesehatan Sebuah Pengamatan Proses Belajar Mengajar dalam Pendidikan. Jogjakarta: Graha Ilmu

7. Notoatmodjo S. 2012. Promosi Kesehatan dan Perilaku kesehatan. Jakarta : Rineka Cipta

8. Departemen kesehatan RI. 2010. Indonesia sehat. Indonesia sehat. Jakarta

9. Mubarak.2007. Promosi Kesehatan Sebuah Pengamatan Proses Belajar Mengajar dalam Pendiidkan. Yogyakarta: Graha Ilmu 